\title{
Dartmouth and the Debate Over Ski Jumping in NCAA Competition
}

\author{
Dennis Gildea \\ Springfield College
}

\begin{abstract}
This essay details the issues that were raised in discussions about the wisdom of eliminating ski jumping from the order of events in NCAA championship competition, a discussion that culminated in 1980 when the NCAA Skiing Rules Committee voted unanimously to drop ski jumping. The event had been an integral and popular part of intercollegiate skiing competitions since 1910 when Dartmouth met McGill in the first meet. More significantly, this essay examines Dartmouth's resistance to the ruling eliminating jumping, a resistance that was fueled not only by the school's pioneering role in skiing but also by a complex set of cultural issues that emerged throughout the 1970s at Dartmouth and that challenged the traditional outdoor ethos of the college.
\end{abstract}

Shortly after the last of the snow from the March blizzard of 1993 melted in northern New England, the wrecking crew moved onto the Dartmouth College golf course in Hanover, New Hampshire, and began dismantling the ski jumping tower. Within the small subculture of North American ski jumpers, the demise of the Dartmouth jump was big and sad news. Elsewhere in the mass-mediated sporting culture, the event went unnoticed and certainly unlamented. Yet the Dartmouth jump, erected in 1921 and the oldest campus jump in the United States, was to intercollegiate skiing what the Yale Bowl is to intercollegiate football-a historical landmark, a symbol of a time when college athletics were becoming organized, formalized, and popularized (Bradley, 1993).

The Dartmouth jumping tower was demolished and not replaced because in 1980, just two months after the Winter Olympics were held in Lake Placid, the Skiing Rules Committee of the National Collegiate Athletic Association, a group made up of four college ski coaches and an athletic director, voted unanimously to drop ski jumping from NCAA competition, thus ending a debate that began officially in 1975 (Robbins, May 1980). Jumping had been a part of intercollegiate skiing competition from its beginning, and the beginning in the United States occurred in 1910 when the Dartmouth Outing Club, founded a year earlier by a student, Fred H. Harris, held the first Dartmouth Winter Carnival (Widmayer, 1938). Norwegian immigrants, particularly those in the Upper Midwest, had made ski jumping a sport that excited large crowds of spectators, and Harris introduced that excitement to

The author is an associate professor of communications at Springfield College in Springfield, MA. 
Eastern collegiate audiences by making the jump "the centerpiece of the Dartmouth College Winter Carnival" (Allen, 1985).

Of course, from 1910 to 1980 when the NCAA eliminated ski jumping from its competitions, the very nature of skiing had changed in terms of dominant disciplines from the Nordic style emphasizing jumping and cross country to the Alpine or liftserved downhill style (Allen, 1993). Still, even in the 1970s, jumping remained exciting and popular, consistently proving to be the one event in intercollegiate competition that produced even a small amount of revenue from spectator appeal (Morton, personal communication, March 13, 1995).

Considering both the tradition of the event and its relative popularity, the question can be raised: why in 1980 did the rules committee vote to eliminate ski jumping? Moreover, what schools favored dropping or keeping the sport and why? Not surprisingly, Dartmouth, in large part because of its tradition, led the resistance to ban jumping and persisted in defying the ban long after others sympathetic to jumping gave up the ghost. On this issue, Dartmouth lived up to its motto: Vox Clamantis in Deserto - a voice crying in the wilderness. However, this essay argues that Dartmouth's resistance to change in the competitive skiing format came about not just because of its pioneering role in winter sports, but also because of a complex set of cultural issues that had seemingly little to do with skiing but which, nevertheless, helped fuel Dartmouth's fight to preserve jumping.

This essay will be divided into two sections. The first will offer a brief history of the move to drop ski jumping from NCAA competitions and outline the reasons why many skiing coaches felt that in 1980 the event was expendable. The second section will deal with Dartmouth's reaction and resistance to the ban.

\section{The NCAA Debates Ski Jumping, 1975-1980}

In 1975, the NCAA Skiing Rules Committee, the governing body of intercollegiate skiing, surveyed coaches on the question of dropping jumping from the championship format. Eighteen coaches favored the elimination of the event, seventeen opposed it. Two years later the same committee raised the question again, and Ski Racing, the only North American journal to cover competitive skiing extensively, took its own survey and found opinions more scattered. The paper did not offer figures, but instead reported: "Some coaches supported the move nationally, but opposed such action regionally. Others felt the best answer would be to split the championships into Nordic and Alpine only competitions. Many objected strongly to any change in format" (Porter, Nov. 11, 1977). However, Ski Racing noted that only ten of the twenty-two colleges represented in the 1977 NCAA meet had jumpers qualified for the championship, and of that number, only five teams scored points in jumping (Porter, Nov. 11, 1977). As early as 1977, then, it seemed likely that the rules committee would recommend to the NCAA Executive Committee that jumping be dropped. Such a threat prompted Don A. Metivier, executive editor of Ski Racing, to argue for the retention of jumping.

Perhaps college coaches — at least some of them — have lost sight of the premise that skiing is supposed to be a team sport and a sport to be practiced and performed by students as part of their entire educational process...Skiing... 
is a sport of great traditions. There can and should be changes, and there have been, but to allow a minority of opinion to dominate an issue as vital to the traditions of college ski competition is... wrong (Nov. 11, 1977).

In fact, Metivier was wrong in claiming that the move to eliminate jumping was spawned by a "minority of opinion." Jeff Hastings's collegiate jumping career spanned the period of the debate and the ultimate decision. Hastings, who finished fourth on the large hill in the 1984 Olympics in Sarajevo, making him the most successful American-born jumper in Olympic history, was a student at Williams College in Williamstown, Massachusetts, like Dartmouth, an elite Eastern liberal arts college with a long skiing tradition. "As a jumper, I was one of the few people who cared one way or the other. Most of the coaches were sick of problems with facilities and of trying to get Norwegian recruits so they could be competitive. The issue (of dropping jumping) was being discussed by powers greater than me. It seemed to be a steamrolling proposal that nobody could get in the way of" (personal communication, March 8, 1995).

Interwoven in Hastings's comments are three of the issues that doomed ski jumping on the intercollegiate level: the shift of power from the Eastern liberal arts colleges to the larger state-supported schools; problems with jumping facilities, which involved both disrepair and the lack of modern, time-saving grooming technology; and the recruitment of foreign jumpers. Among the other issues raised against continuing jumping were: the skyrocketing cost of insurance; the relative lack of American jumpers who were both academically qualified and interested in intercollegiate jumping rather than pursuing a spot on the national team; the growing likelihood by 1979 and 1980 that there would be a combined men's and women's team championship under the aegis of the NCAA and the fact that women did not jump competitively; and, the overarching reason brought up by many coaches, their perception that cost-cutting changes had to be made to save the entire sport of skiing from extinction on the intercollegiate level (LaCasse, personal communication, April 12, 1995).

The athletically greater powers of American skiing, the University of Vermont in the East and Colorado University, Wyoming, and the University of Utah in the West, were all large state-supported schools that were coming to rule the collegiate scene both competitively and in terms of holding seats on the rules committee. In the East, Vermont was establishing itself as the skiing power, usurping a place atop the Eastern Intercollegiate Ski Association rankings that for decades belonged to Dartmouth. Hastings said, "By 1980, Williams skied on a less-competitive basis, not like UVM where winning was everything" (personal communication, March 8, 1995).

John Morton, a Middlebury College graduate who became the ski coach at Dartmouth in 1978, has observed that upon taking the job he soon learned: “... [T]o my amazement, I discovered that Dartmouth's historic prominence in skiing was regarded with complacency in Hanover" (Morton, 1992). Beyond the realm of intercollegiate skiing, the Western schools, in particular, with big-time football and basketball programs were more dominant voices within the NCAA membership than were the Eastern liberal arts colleges of the time. Chip LaCasse, head skiing coach of Vermont, was a former jumper and jumping coach and was the chairman of the Skiing Rules Committee. Other members in 1980 were Pat Miller of Utah, 
Quentin Skinner of Wyoming, Tim Hinderman of Colorado, all ski coaches, and Tom Parac, athletics director at Montana State. Dartmouth was not represented, although, ironically, Jim Page, a Dartmouth alumnus, a former Nordic combined Olympian (a sport that combines the results of jumping and cross-country ski racing to determine an overall winner) and a man who served as head coach at Dartmouth and as chairman of the rules committee until he left coaching after the 1978 season, introduced the proposal to drop jumping in 1977 (Porter, Nov. 11, 1977).

Hastings also alluded to two other frequently cited objections to jumping: lack of good, safe jumping facilities and the necessity of recruiting Norwegian jumpers who were superior to Americans and were sure scorers in championship competitions. Jumping was always the last event on the NCAA championship schedule, typically following two days of Alpine and cross-country races, which, in the case of a tight meet, meant that the school with the best jumpers would win the championship. Since the late 1950s and early 1960s when University of Denver coach Willy Schaeffler began importing Europeans in all disciplines and won ten consecutive NCAA championships, the arms race to recruit Europeans, especially jumpers, began in earnest (Bowen, 1963).

When it appeared that intercollegiate jumping competition was threatened, if not doomed, Ski Racing attacked the foreign-born jumpers, urging that every effort be made to "resuscitate jumping," even if that meant "taking a step backwards to where collegiate jumping is once again a development circuit for American skiers instead of a top-level competition for foreign athletes" (Porter, Nov. 9, 1979). In the 1980 NCAA meet, the last in which jumping was contested and the only time it was held first in the order of events, Jorn Stromberg, a Norwegian skiing for Wyoming, won. Of the top twenty finishers, only four were Americans, one each from Northern Michigan and Dartmouth and two from St. Lawrence (Porter, March 21, 1980).

Hastings, significantly, did not compete on the intercollegiate level in 1980, opting instead to try for a spot on the U.S. team in what turned out to be a failed attempt at making the Olympic squad that winter.

There were a few athletes who skied for colleges, but the U.S. ski team was not particularly education-oriented. The coaches focused on international competition, and they didn't see the colleges as an area to build talent but as a distraction. Jumping was controlled in those days by Central Division (of the U.S. Ski Association, that is, the Upper Midwest), and there were a bunch of coaches there who were not college educated themselves, and they took young talent and threw them into international competition. So there's no question that at the time the U.S. did not have the numbers or the talent to field a lot of college teams. What you ended up with was a lot of B-team Alpine guys putting on jumping skis to round out the team (personal communication, March 8, 1995).

Bud Fisher, the Williams coach then and now, opposed eliminating jumping because of its traditional place in the sport, but he acknowledged, "The flip side of the coin for me was that I remember going through a three-year period when I had no more than one applicant who was interested in jumping. And that's to say nothing about whether he was qualified to compete or to come to Williams College. It was a losing battle to find jumpers." Fisher, like most of his colleagues in the Eastern liberal arts colleges, did not recruit foreigners (personal communication, March 10, 1995). 
At the 1980 NCAA meet, skiers flew off the seventy-meter hill at Lake Placid because the host school, Vermont, had no jumping facility, a situation it shared with most of the other NCAA ski schools. Vermont coach LaCasse said, "At UVM, we used a jump owned by the nearby town of Williston, but it wasn't large enough for championship standards. And it got to the point that nobody could use it because of liability costs. This was around the time of the Sunday case in which a skier sued Stratton Mountain and won. That case had huge ramifications for all aspects of skiing, especially for ski jumping" (personal communication, April 12, 1995).

LaCasse's reference was to a suit brought by James Sunday, a beginning skier from Burlington, Vermont, who caught his ski tip in underbrush protruding through the snow on a slope at the Stratton Mountain ski area in Southern Vermont. Sunday fell, struck his head on a rock, and was paralyzed from the shoulders down. Sunday sued, and on June 10, 1977 the Vermont Superior Court awarded him 1.5 million dollars, marking the first time that a defendant had successfully pursued a civil suit against a ski area in Vermont. In 1951, a Federal District Court judge in Burlington ruled against the defendant in a similar suit, reasoning that a skier assumed certain risks inherent to the sport for which the ski area operators were not liable. Until the Sunday ruling, that case held as precedent (New York Times, June 11, 1977).

What was more stunning to ski area operators, though, was the amount of the award, which sent liability rates soaring. Those colleges with their own jumping facilities were insured under the college's umbrella insurance plan and did not suffer unduly from rising insurance rates. Those who did not have their own facility, and by 1977 that was the majority of colleges with ski teams, either had to dig deep to help defray insurance costs at the area they used, or, as was more often the case, watched the community jumps fold because of insurance costs (Aldrich, personal communication, April 6, 1995). The combination of rising insurance rates, the dying off of immigrant and first-generation Scandinavian-American jumpers who worked to keep the community jumps alive, and dwindling participation by young athletes forced numerous small-community jumping areas to close during this period (Kent, Oct. 24, 1980).

LaCasse of Vermont and other college coaches were especially concerned about schools dropping skiing because of the expense, the lack of interest, and the inability to be competitive nationally, an inability that some attributed to poor jumpers and jumping facilities (Porter, Nov. 11, 1977). Among many old-time Eastern jumpers and jumping officials, LaCasse is as beloved as a week-long January thaw. He is widely, if not quite accurately, regarded as the man who led the move to kill intercollegiate jumping. "I wasn't leading anything; it was leading me," LaCasse said. "I would've kept it if we had a ray of hope of doing it. But I saw a huge problem-the real chance of losing the whole sport" (personal communication, April 12, 1995).

Bill Marolt, who in 1977 was the head coach at Colorado and the chairman of the rules committee, reported in a meeting of the committee that Fort Lewis College in Durango, Colorado, long a skiing power under its coach, Adolph Kuss, was on the verge of dropping skiing as an NCAA sport. The recently organized and corporate-funded National Collegiate Ski Association, which catered to college ski programs on both the varsity and club level and which did not compete in jumping, 
served as an attractive alternative to the NCAA for some colleges (LaCasse, personal communication, April 12, 1995). Marolt also said that there were only three healthy four event (slalom, giant slalom, cross country, and jumping) programs in the Rocky Mountain Division and few jumping facilities and coaches to pursue the event (Porter, Nov. 11, 1977). The implication was clear, at least as far as the Western schools were concerned: drop jumping and save the sport in general.

In 1978 the NCAA began to pay the expenses of the top six competitors in each event at the skiing championships, and by 1979 the NCAA proposed to pay the expenses of all competitors at the championships. The organization made it clear that it intended to limit the size of the field in an attempt to ensure championshipcaliber competition for its money. Moreover, the NCAA put the burden on the Skiing Rules Committee to find ways to limit the field. Virtually every program had far more qualified Alpine skiers and some had more qualified cross-country skiers than they had jumpers. LaCasse told Ski Racing, "I have five top Alpine skiers who on any given day could win an event and I wouldn't want to take any one of them off my team" (Porter, Nov. 11, 1977).

By 1979, LaCasse and others saw the solution to the dwindling number of ski programs in the NCAA - join forces with the women's programs, which at that time were competing in single-gender championships under the aegis of the Association of Intercollegiate Athletics for Women (AIAW). A joint men's and women's championship, with the team champion determined by combining the scores, would increase the numbers, improve the quality of the competition, guarantee that the NCAA continue to pay per-diem expenses, and certainly fit into the NCAA's plan to offer championship competition in women's sports. Moreover, if a school had both a men's and women's team competing under NCAA jurisdiction, it could count not one but two ski programs, thus increasing the number of skiing programs nationally and satisfying the NCAA's minimum standard of forty varsity programs required to hold a championship (LaCasse, personal communication, April 12, 1995). The women competed in two downhill events, an individual cross-country race, and a cross-country relay. "We were looking at interfacing our programs with the women so we could put on an equitable championship," LaCasse said. "The women didn't have jumping, so we proposed adding a relay. I took the idea (in 1979) to the NCAA Executive Committee, and (Walter) Byers (the NCAA executive director) thought it was great. We had our first combined championship in 1982, the first for any NCAA sport" (personal communication, April 12, 1995).

For a variety of compelling reasons, college ski jumping was doomed. It had its loyal supporters, most notably, Dartmouth, Williams, Middlebury College, and St. Lawrence University, all located in the Northeastern snowbelt and all small liberal arts colleges with long, proud skiing histories. But even among some of those colleges, the contingencies of present-day reality loomed over tradition and ski-culture idealism. Middlebury coach Terry Aldrich remembered: "Philosophically, we were for keeping jumping. I, and most of the other coaches, were old four-event skiers, and I couldn't imagine the sport without jumping. Realistically, though, I knew it wasn't going to continue. There seemed to be so many compelling reasons against it" (personal communication, April 6, 1995). 


\section{Tradition, Transition, and the Dartmouth Resistance}

As of the 1981 season, ski jumping was no longer part of the NCAA championship format. Shortly after the rules committee's decision was made in April 1980, the Eastern Intercollegiate Ski Association announced that it would try to keep ski jumping alive as a nonscoring fifth event at the Eastern college carnivals, as the meets were called, taking their name, no doubt, from Dartmouth's celebrated winter carnival. St. Lawrence University in Canton, New York, the University of New Hampshire, and Dartmouth were willing to hold a jumping contest in their carnivals. Dartmouth and St. Lawrence had on-campus jumps; New Hampshire used the Gunstock Nordic Association jump near Laconia, less than an hour's drive from campus (Lukens, Oct. 24, 1980). After 1981, only Dartmouth persisted, rather grandiosely referring to its competition by the mid-1980s not only as the Winter Carnival Jump but also the Eastern Collegiate Jumping Championship (U.S. Eastern Division Nordic Skiing Guide, 1986). Significantly and not surprisingly, only a few college jumpers competed; most of the jumpers came from Eastern club teams (Morton, personal communication, Sept. 27, 1995). After 1991, even Dartmouth stopped featuring jumping in its carnival on the Vale de Tempe jumping hill, as the big jump was known. The jumping tower had fallen into disrepair, the college's administration was unwilling to bear the cost of repairing or replacing it, and there simply were not enough college jumpers at Dartmouth or elsewhere to warrant the effort (Chivers, personal communication, April 24, 1995).

Still, the question remains: why, in the face of such overwhelming odds against continuing college jumping, did Dartmouth alone try to keep it alive in the 1980s? The most obvious answer, of course, is the Dartmouth Winter Carnival tradition, the "Mardi Gras of the North," as Dartmouth Outing Club founder Fred Harris (1920) referred to it in a National Geographic piece extolling the glories of skiing at Dartmouth. Rooted though they may have been in the college's skiing tradition, the reasons for Dartmouth's fight to maintain jumping and its efforts to continue the sport following the ban were also shaped by a larger battle throughout the 1970s involving the culture of the institution. I argue that caught in a maelstrom of seemingly unrelenting cultural change on a variety of fronts, some at Dartmouth and in the community of Hanover came to view ski jumping as a threatened symbol of a ruggedly outdoors, manly ethos that they cherished. At Dartmouth, the 1970s was a particularly difficult and defining decade, because it marked the twilight of the old Fred Harris-Dartmouth Outing Club era and the dawning of a new and, for some, startlingly protean Dartmouth.

It is difficult to overstate the athletic and social importance of the carnival to Dartmouth alumni, especially to those who graduated before the 1970s. Writing in 1939, David Bradley, captain of the 1938 ski team, noted: “...[W]inter sports are the outstanding characteristic of the college. It is largely by this that Dartmouth is known not only in New England, but abroad" (1939). Nevertheless, enthusiasm for Winter Carnival eroded during the early-1970s, particularly during the years of protest over American involvement in Vietnam (Bradley, personal communication, April 21, 1995). When in 1993 former Dartmouth coach John Morton spoke of the Winter Carnival in another Bradley article, it was in the past tense, as if it were no longer what it used to be. "The Dartmouth Carnival: It was the high point of winter - all that depth of tradition and community spirit" (1993). 
For generations of Dartmouth alumni, it was this event, a celebration of the winter outdoors and the seemingly concomitant dominance of the Dartmouth ski team, that gave the school its special identity. Winter Carnival provided the setting for a 1939 Hollywood film that deals with skiing and, more importantly for the plot, the crowning of the Winter Carnival Queen of the Snows, played by Ann Sheridan. The genesis of the film was a short story in The Saturday Evening Post written about the carnival by Hanover resident Corey Ford (May 29, 1937). Inspired by the story and his winters as a Dartmouth undergraduate, Hollywood producer Walter Wanger, class of 1915, developed the idea for the film (http://dartreview. com/archives/2008/02/fitz_and_schul). Because Dartmouth did not go coed until 1972, the last Ivy League school to do so, carnival weekend attracted college women from throughout the East. One of the first carnival queens was crowned in 1928, that honor going to a Smith undergraduate named Florence Rice, the only daughter of sportswriter Grantland Rice (Fountain, 1993).

The social aspects aside, the ski competition provided the core of the carnival, and ski jumping was considered the most important and popular event. Writing in 1938 of the early years of carnival competition, Charles E. Widmayer noted: "Just as in the modern Dartmouth Carnival, the ski jumping on Saturday afternoon was a breath-taking thrill for the hundreds of spectators who crowded about the landing hill" (1938). Understandably, most of those spectators were interested in seeing Dartmouth win. In a preseason story on the prospects of the 1939 ski team, a writer in the Dartmouth Alumni Magazine lamented graduation losses but tried to reassure readers that the returning skiers would be strong enough to allow the team to finish "first for at least one more winter." The story concluded: "If it proves to be otherwise, the world has come to an end as far as the Dartmouth students are concerned" (January 1939).

Forty years later, the correlation between the end of the world and the relative strength of the Dartmouth ski team was far less direct. Morton took over as head skiing coach at Dartmouth for the 1979 season. He was on the 1972 and 1976 American Olympic teams as a biathlon skier. In college, he was primarily a crosscountry skier, although he occasionally jumped and was used as a four-event skier. The fact that he had a broad skiing background was raised during his interview for the job (Morton, personal communication, March 13, 1995), While at Dartmouth, he fought fiercely to retain jumping. Morton acknowledges the list of reasons offered for eliminating the event, but he persists in labeling them a "smoke screen."

All the coaches who were on the rules committee were having significant headaches with their jumping programs, especially with their facilities. And all of them were spending two or three scholarships to recruit Scandinavian jumpers. They figured they could dispense with the jumping event and focus on Alpine and cross country. They threw up the smoke screen that jumping wasn't reaching a broad enough audience, or that there weren't enough American jumpers being developed. That was bullshit. These guys then used the same scholarships to recruit more Scandinavian cross-country skiers. I feel confident this is a big part of what happened (personal communication, March 13, 1995).

Morton's assessment of the jumping question is that the coaches on the rules committee abandoned jumping for their own advantage; LaCasse, on the other hand, 
maintains that the committee jettisoned jumping to save intercollegiate skiing as a whole. It is entirely possible, of course, that both are right in their own way. For his part, Morton remembers the frustration he felt engaging in the battle against overwhelming odds. "It was a very difficult situation for me. As the Dartmouth coach, I was committed to do everything I could to stop the move. Basically, they beat me" (personal communication, March 13, 1995).

When Morton uses the singular "me" in the above statement, he does so with more than a trace of irony. When he was offered the coaching job at Dartmouth, Morton thought he had a chance to "be at a place where skiing was the premier sport." Instead, he found what he characterized as an athletic and college administration that was apathetic about skiing. "They seemed to reason that Dartmouth was always strong, so we don't have to worry about skiing. The administration put more emphasis on what they called the 'highly visible sports': football, basketball, hockey, baseball, and even crew" (personal communication, March 13, 1995).

The traditional American spectator sports, rather than skiing, were getting the greatest financial support, including special treatment by the admissions' office, Morton said. At least some of this support, though, may be attributed to another unique Dartmouth tradition: the ski program was operated under the jurisdiction of the Dartmouth Outing Club, not the athletic department. "The ski team ended up getting the short end of the stick from the administration on several important matters. They didn't represent us as a varsity sport, and we felt like second-class citizens" (personal communication, March 13, 1995).

Even the college's most celebrated winter event was diminished in importance, and despite the fact that Dartmouth won the NCAA skiing championship in 2007 for the first time since 1976 when it was cochampion with Colorado, Winter Carnival remains somewhat ignored by contemporary undergraduates. Writing in the student daily of having experienced his first Winter Carnival, a freshman reporter pointed to "evidence of the decline of a once-great tradition." The writer goes on to quote the resident of a nearby town as saying, "[Carnival] used to be one of the highlights of the winter. Now, not so much" (Batchelor, Feb. 16, 2009). The transformation in attitude about the carnival is symptomatic of other changes at Dartmouth, most of which began in the late-1970s. By 1979, Morton's first year as ski coach, Winter Carnival was still held on the second weekend of February, and Dartmouth men were still jumping, but much about life on the isolated Hanover campus was changing or had already changed. At a college that reveled in its tradition, particularly the ruggedly outdoors masculine tradition embodied by the Dartmouth Outing Club and its centerpiece, ski jumping, the values of the old culture were being challenged and altered. Granted, the same thing was happening on many campuses in the United States in the 1970s, but Dartmouth proved more resistant to change than many campuses. It had the decades-old ethos of its frozen winters and the old-boy power network to bolster it against the forces of change. A 1979 Esquire article noted:

The geography also has a direct effect on the type of student that chooses Dartmouth over its more urban Ivy League competitors. The men of Dartmouth are the Marlboro men of the East. Dartmouth is a jock school and an outdoorsman's school. Almost everybody plays something. Almost everybody runs or skis or canoes or climbs or hikes. That Dartmouth men tend to be macho is "a 
legitimate statement," according to the school's soft-spoken president, John Kemeny (Merton, June 19, 1979).

Ironically, John Morton made much the same point, although his emphasis was on the positive aspects of the college's identity. Dartmouth's "ace card was its rural location and its emphasis on the outdoors" (personal communication, Sept. 27, 1995).

An athletic, macho student body or alumni do not necessarily mean an intransigent group, and it would be a gross generalization to suggest that this was the case with all Dartmouth men, including those associated with the ski team, and that this intransigence fed the resistance to dropping ski jumping from intercollegiate competition. In his elegiac article on the history and the dismantling of the Dartmouth jumping tower, David Bradley treats the jump symbolically, observing that it was just two years the junior of a campus landmark, the Baker Library Tower on the campus green. "For 64 years the two towers stood as landmarks-glad reaffirmations of the two Dartmouths, the indoor and the outdoor, born together in Eleazar's [Wheelock] log-cabin college" (1993). Moreover, Bradley treats the two towers, one symbolic of the intellectual life of the college, the other symbolic of the outdoor, manly spirit, as being of equal importance. The equation suggests, as Fred Harris and many of his successors at Dartmouth argued, that ski jumping was, as the Ski Racing editorial maintained, a part of the entire educational process (Metivier, Nov. 11, 1977).

At Dartmouth in the 1970s, the educational process was in transition. From 1971 to 1980, the Dartmouth way of life was beset by numerous changes or challenges, not the least of which was women being admitted for the first time in 1972, just three years after the college celebrated its bicentennial. That anniversary coincided with two central changes: Kemeny's installation as the college's president and the hiring of the first two women faculty. Kemeny, who had been chairman of the mathematics department, represented a departure from the norm of the Dartmouth man and the Dartmouth administrator. He was a Hungarian Jewish refugee who as a teenager had escaped from a Nazi concentration camp. And he was a Princeton graduate. Bradley claims that the traditional importance of skiing at the college became "very much diminished" when the school's leaders were "not Dartmouth people" (personal communication, April 21, 1995).

Under Kemeny's leadership, Dartmouth as a bastion of the white, socially elite male began to disappear. The transition to a coed campus, in particular, did not occur smoothly. Some Dartmouth men, generally fraternity men, surrounded the women's dormitory in the evenings and serenaded them with obscenity-laced songs. The women were referred to by the derogatory term "cohogs," a term arrived at by blending coed with quahog, a clam found in the New England coastal waters and, at Dartmouth, a term used for female genitalia (Merton, 1979).

In 1975, a traditional fraternity competition called Hums, in which the brothers composed and performed songs, a prize for the most creative and original entry went to an effort sang to the tune of "This Old Man." In part, the lyrics went: "Our cohogs, they play one,/ They're all here to spoil our fun./ With a knick-knack, paddy-whack, send the bitches home,/ Our cohogs go to bed alone./ Our cohogs, they play seven,/ They have ruined our masculine heaven" (Merton, 1979).

If life at Dartmouth were heaven for some men, the 1970s were shaping up as Paradise Lost. By 1979 Dartmouth women became numerous and secure enough 
so that, joined by some college men, they protested such blatant and more subtle forms of discrimination. In addition to going coed, traditional Dartmouth was shaken in substantial ways, with most of the issues coming to a head between 1978 and 1980. Even the academic calendar changed from a traditional semester system to a ten-week term system which "encouraged students to be present in the summer rather than in the snow," a vast departure from the college's heritage (Trillin, May 7, 1979).

Other changes and challenges included: a decade-long heightened effort to recruit minority students and faculty, including American Indians, a population the college was in principle founded to educate; disbanding the R.O.T.C. program; in 1978, the faculty voting 67-16 in favor of abolishing the college's powerful fraternity system; in 1980 Dr. John Steel's becoming the first alumnus (class of '54) elected to the college's board of trustees without the endorsement of the Alumni Council, a vote that was seen as symptomatic of the rift between the "old" and "new" Dartmouths; that same year the conservative Dartmouth Review, backed financially by alumni dissatisfied with the direction the college was taking, began publication as an alternative newspaper to the established daily The Dartmouth; and from 1971 through 1980, the school attempted and often failed to enforce its mandate against using the Indian as the mascot, a sporting symbol which was dropped because it was "inconsistent with the present institutional academic objectives of the college" (Kleiman, Aug. 3, 1980). Throughout the decade, Dartmouth tried to phase out use of Indian cheers, such as, "Scalp'em," and "Wah-hoo-wah," which also served as a greeting among alumni. The Kemeny-appointed Indian Symbol Study Committee determined that "Wah-hoo-wah" was a Sioux phrase for the act of sodomy. Some Indian alumni, adding fire to a battle that raged in the pages of the Dartmouth Alumni Magazine, insisted that it meant "snow, ah, snow." Calvin Trillin wrote: “...Dartmouth had undergone so many changes so quickly that to some alumni it seemed transformed into some other institution" (May 7, 1979).

When the board of trustees met on Winter Carnival weekend in 1979, women demonstrated outside the meeting place for equal access in admissions and genuine equality on campus. The Afro-American Society demonstrated against Dartmouth's investments in South Africa by placing a coffin and simulated grave markers alongside the traditional ice sculptures on the campus green. The college grounds crew removed the display and threw it in the trash. The weekend's protests culminated with a joint demonstration by Indians, African-Americans, and their supporters amid the ice sculptures on the green. Protestors concluded the demonstration by spray painting the major ice sculpture, always a signature piece of the carnival, red and black. (Trillin, May 7, 1979). Clearly, this was not the celebration of winter Fred Harris had in mind in 1910 when he started the Dartmouth Winter Carnival.

In the throes of such transformation and protestation came the debate over dropping ski jumping from NCAA competition, another threat to Dartmouth tradition. Again, to claim that the ski team's fight against the NCAA proposal was similar in nature and as culturally reactionary as the other battles being fought would be a mistake. Still, from Dartmouth's perspective, the debate was taking place in the context of these other, more institutionally central transformations, and that context could not help but to color or add to the intensity of feeling about the jumping question. Simply put, many at Dartmouth did not want to yield another tradition, especially one as essential to the extracurricular identity of the college as ski jump- 
ing and one they felt was being unjustly threatened by outsiders, personified by LaCasse at the hated UVM. "The ski jumping issue was peripheral to all the other things that were going on," Morton said, "but it was all part of a bigger issue for Dartmouth as an institution. It was, and still is, having a hard time defining what it wanted to be" (personal communication, Sept. 27, 1995).

Old-time Dartmouth skiers know what the college is not: it is no longer a place where a student can learn to fly off the big jump. It is no longer the same place that Fred Harris and his pioneering Dartmouth Outing Club members made, and maintained, and loved. Dartmouth had been wrenched into change by forces it was unable and sometimes unwilling to control. In going against the new powers of the intercollegiate skiing world, the NCAA, and, as it turned out, even its own college administration, the Dartmouth ski team lost a cultural battle to retain a cherished tradition. Where the big jump once towered above the ravine known as the Vale de Tempe now stands a bronze plaque on a slab of New Hampshire granite. It was dedicated in June 1994, the idea originated by and the work paid for not by the college administration but by the Hanover Rotary Club (Bradley, 1993). A number of former Dartmouth jumpers and coaches gathered for the dedication at the place where in their youth they tested their courage and grace by riding the wind on a pair of skis. About the occasion, Bradley wrote:

Farewell then to Carnival jumping, the heart of winter exuberances at Dartmouth. Something local and precious. Yale has its incomparable Whiffenpoofs, Harvard its Head-of-the-Charles. At Dartmouth it was Carnival and convocation of the big hill. It's gone now, the gorgeous length of that great jump junked-the first big college hill in the country, for decades the best, and, as it turned out, the last. Students of the future will not notice the dreadful emptiness among the pines on the golf course....(Bradley, 1993).

\section{References}

Allen, E.J.B. (1993). From Skisport to Skiing: One Hundred Years of an American Sport, 1840-1940. Amherst, MA: The University of Massachusetts Press.

—. (1985). The Making of a Skier: Fred H. Harris, 1904-1911. Vermont History, 53(1), 5-16. Batchelor, J. (2009, Feb. 16) A Carnival to Remember? The Dartmouth, 4.

Bowen, E. (1963). The Book of American Skiing. Philadelphia: J.B. Lippincott.

Bradley, D. (1993, Winter) Big Jump. Dartmouth Alumni Magazine, 16-20.

- (1939). They've Gone Out. In H. Putnam (Ed.), The Dartmouth Book of Winter Sports, 283. New York: A.S. Barnes.

Dartmouth Alumni Magazine. (1939, January). Hanover, N.H.: Dartmouth College, 23.

Ford, C. (1937, May 29) Echoes that Old Refrain, The Saturday Evening Post, 10-11; 66-69.

Fountain, C. (1993). Sportswriter: The Life and Times of Grantland Rice. New York: Oxford University Press.

Fry, J. (2006). The Story of Modern Skiing. Hanover, N.H.: University Press of New England. Grudzien, M. (2008, Feb. 8) A Look Back at the 98-year History of Winter Carnival, The Dartmouth, p. 2.

Harris, F.H. (1920). Skiing over the New Hampshire Hills. National Geographic, 151-164.

Kent, R.B. (1980, Oct. 24) Ski Jumping Is Dying in Maine, Ski Racing, 20.

Kleiman, D. (Aug. 3, 1980) Dartmouth Alumni Trying to Bring Back the Indian, The New York Times, 16.

Lukens, M. (1980, Oct. 24) NCAA Jumping Limited, Ski Racing, 20. 
Merton, A. (1979). Hanging on (By a Jockstrap) To Tradition at Dartmouth. Esquire (New York, N.Y.), 91, 58-67.

Metivier, D.A. (1977, Nov. 11) College Jumping Should Stay, Ski Racing, 18.

- (1980, March 21) Minimize the Number of Foreign Athletes, Ski Racing, 4.

Morton, J. (1992). Don't Look Back. Harrisburg, PA: Stackpole Press.

The New York Times. (1977, June 11), \$1.5 Million Is Awarded to Paralyzed Vermont Skier, 9.

Porter, G. (1977, Nov. 11) College Jumping: At Edge of Extinction, Ski Racing, 25-26; 28.

—. (1979, Nov. 9) Collegiate Jumping Faces Extinction in '81, Ski Racing, 1; 8.

- (1979, Nov. 9) Return to the Development of U.S. Jumpers, Ski Racing, 5. . (1980, March 21) UVM Dominates Championships, Ski Racing, 6; 19.

Robbins, P. (1980, May) NCAA Drops Jumping; EISA Offers Compromise, Ski Racing, 1; 18.

Trillin, C. (1979). U.S. Journal: Hanover, N.H., The Symbol Is a Symbol. New Yorker (New York, N.Y., 138.

(1986). United States Eastern Nordic Skiing Guide, 71. Vt.: Brattleboro.

Widmayer, C.E. (1938). The D.O.C. Started Something, Dartmouth. The Alumni Magazine, $8-11$. 